\title{
Adaptive Strategies of External Environmental Effects in Digital Entrepreneurship in the Strategic Management Perspective
}

\author{
Teddy Hikmat Fauzi ${ }^{1}$ \\ Benyamin Harits ${ }^{1}$ \\ R. Deni Muhammad Danial ${ }^{2}$ \\ Kokom Komariah ${ }^{2}$ \\ ${ }^{1}$ Universitas Pasundan, Bandung, Indonesia \\ ${ }^{2}$ Universitas Muhammadiyah Sukabumi, Indonesia
}

Doi: 10.36941/ajis-2020-0o4o

\begin{abstract}
The rapid development of information technology and digitalization has formed a specification in the economic field, in the form of a digital creative economy. This economic cluster generally refers to entrepreneurship developed through the use of the internet and digital advancements to create business opportunities with excellence in the value of services and products. In strategic management, the development of technology that is widely adopted in company policy in improving service and product quality is an external element. In addition to having an extraordinary impact on consumption patterns, distribution and production, information technology is now able to become a fundamental instrument as the essence of creating value for products and services. This leads to a paradigm shift in the strategic management perspective, from the perception of technological externalities to internalities in value creation and policy making. This study seeks to identify shifts in the paradigm of the external environment of technology in contemporary business that develops ICT and the internet as the basis for digitalization and virtualization of exchanges of products, services and transactions between business actors. The results show that unlike conventional companies that respond to technological advances need technological advancements as an added value of their products and services, digital entrepreneurship uses technological advancements as a core part of product development and value creation. This study identifies important elements regarding adaptive strategies of external environmental effects in digital entrepreneurship. The results show that the shift in technological externalities to integrated digital entrepreneurship is capable of digitizing the creation of values and opportunities and operating digital-based businesses.
\end{abstract}

Keywords: adaptive strategies, digital entrepreneurship, external environment, internet marketing, strategic management

\section{Introduction}

Change strategy management is a managerial decision and activities that lead to the determination of the organization's long-term performance, which includes analysis of the internal and external environment, accompanied by the formulation of the vision and mission and objectives of the organization to deal with that environment. The environment here is included in the company's 
external and internal environment. Many factors affect the performance of small industries including the influence of internal and external factors. Setyowati (2015) stated that the performance depends on the ability to manage these two factors through the analysis of environmental factors and the establishment and implementation of business strategies. External factors include macro and micro environments consisting of demographics, politics, technology, economics, socio-culture, suppliers, consumers, competitors, distributors, government institutions, labor, and creditors (Chung et al., 2007). What is referred to as general environments refers to the composition of various dimensions in society that affect the industry and the companies within it. The grouping is divided into several segments, namely: demographic, economic, political and legal, sociocultural, technological, global, and physical environment. What the company can do is analyze trends in each segment and predict the effect on its activities. Today, technological advances have pushed almost all forms of business to adapt to take advantage of and use information technology for manufacturing products and services, distribution and marketing.

In strategic management, the development of technology that is widely adopted in company policy in improving service and product quality is an external element. Unlike conventional companies that respond to technological advances need technological advancements as an added value of their products and services, digital entrepreneurship uses technological advancements as a core part of product development and value creation. Specifically, this study analyzes digital entrepreneurs by emphasizing on adaptive strategies that are applied integrated by new entrepreneurs in the field of technology to create value and opportunities and business operations. In general, digital entrepreneurship is a phenomenon that has emerged through the development of information and communication technology. Guthrie (2014) states that digital business is the sale of products or services through electronic networks. The digital economy opens up opportunities for entrepreneurs to create different business areas through an electronic trading model (Turban et al., 2008). This shows that the latest developments indicate a paradigm shift in the effect and utilization of technology for digital companies. The findings of this study were obtained from the method used in the form of library research, with qualitative-descriptive analysis. The study findings highlight crucial aspects in the development of adaptive response for internet-based digital companies, which are different from old model companies.

\section{Strategic Analysis of External Environmental Effects}

Strategic management is a series of strategic decision making processes, namely decisions that are long-term, comprehensive, and priority. This strategy is very important because it can influence the overall direction of the company. Errors in making decisions that are long-term, comprehensive and priority are certainly not expected because they can damage stability and threaten the survival of the company. For this reason, an in-depth study is needed in formulating this strategic decision (Cognoscenti Consulting Group, 2016). The formulation of strategic management in the analysis of external and industrial fields as a first step in the process of formulating strategic decisions, namely the implementation of business opportunity assessments that will be encountered. An opportunity is a situation in the general and macro environment, which if processed and used optimally can help the company to achieve its goals. While a threat is a situation in the general and macro environment, which can hinder a company from achieving its objectives. To observe this environment, a strategic manager must understand various external factors that have an influence on the company's internal conditions for achieving competitive advantage.

Along with the rapid development of technology in business and the basics of innovation, the paradigm of technological externalities in the company's internal policy making regarding drastic changes. The first paradigm in strategic management is an old view that considers technology as an external factor that is fully considered to have opportunities and threats for business growth and continuity. This perspective perceived that as one of external elements, technology can be adaptively responded by identifying its influence on the choice of direction and actions of a company and affect 
the organizational structure and internal processes. The external environment can be divided into three related sub-categories, namely: factors in the remote environment, factors in the industrial environment, and factors in the operational environment. The company's external environmental conditions can be described on a continuum, from favorable conditions (benign environment) to unfriendly conditions (hostile environment) (McGee \& Rubach, 1996). Strength outside the company that is uncontrollable so changes that occur in this environment will affect the performance of all companies in the industry. Analysis of the external environment indicates the opportunities and threats facing the company. Idris (2018) stated that the external environment can be classified into two categories, namely integrated views regarding environmental observations and adjustments to company reality and perceptual views. The number of external factors that influence is not constant but is always changing and the intensity of the impact will vary.

There are several critical factors that influence the course of the company's operational activities in an industry, such as economic, technological, political and legal factors as well as social culture. Economic factors include GDP, interest rates, inflation rates, unemployment rates, currency markets, disposable income, and price and wage controls. Technological factors include patent protection, new products, internal availability, telecommunications infrastructure, development of new technologies, industrial transfers, $R \& D$, and automation. Political and legal factors, including antitrust regulations, tax regulations, government stability, regulations on outsourcing, foreign trade regulations, immigration regulations, and global warming regulations. Socio-cultural factors, among others, are lifestyle changes, career expectations, life expectancies, pension plans, health care, birth rates, age distribution of the population, education level, population growth rates and population movements within the region (Cognoscenti Consulting Group, 2016 ).

The analysis of the external environment includes an understanding of various factors outside the company that lead to the emergence of business opportunities. From the company's point of view all the factors above are factors that are outside the company's control (external factors). All external factors provide opportunities and threats for the company to realize its vision, mission and goals. These external factors cannot be controlled by a company without the right strategy in accordance with the changing environment situation. Achieving company goals is visualized in business performance. Today's management in the information age pays much attention to the non-financial aspects which actually encourage and build on the success of the financial aspects, especially in the increasingly competitive business situation now and in the future (Suyono, 2013). Strategic management highlights five variables in industry conditions that must be recognized and taken into account, of threats from new entrants, supplier factors, buyer factors, production factors, competition factors. Riyanto (2018) proposed two main perspectives in managing the external environment. First, the perspective that views the external environment as a vehicle that provides resources (Clark et al., 1994: Tan \& Litschert, 1994). Both perspectives view the external environment as a source of information. The first perspective is based on the premise that the external environment is a vehicle that provides critical resources for the survival of the company (Tan \& Litschert, 1994). This perspective also implies external potential in threatening the company's internal resources. Strikes, deregulation, changes in laws, for example, have the potential to damage the company's internal resources. The second perspective links information with environmental uncertainty. Environmental uncertainty refers to changes in external environmental conditions that are difficult to predict changes. This relates to the ability of organizational members in decision making (Clark et al., 1994).

\section{Technology as a Strategic Element of Corporate Adaptability}

The era of information technology has driven fundamental changes in the order of business practices, the business environment that is full of change, borderless world business activities are the consequences which have implications for increasingly intense levels of competition, both on a local, regional and international scale. A successful business entity is one that is able to demonstrate a high level of adaptive and flexibility with the environment. This leads to the second formation from a 
strategic management perspective to see technology not as a threat and merely an opportunity, but also a fundamental basis in the formation of value and the creation of products and services. The development of the internet since decades has changed the paradigm towards this kind of technology. If previously technology, especially ICT, was considered to only provide added value for services and products, technology was used by first startups as a major component in its services. This changes the patterns of consumption, distribution and production of services and services, as well as digitizing and virtualizing transactions between actors in the market. In this case, top management intelligence in developing innovative, adaptive and comprehensive strategies and aligning with goals is a fundamental factor in the competitive advantage of its technology-based business. The concept of continuous improvement is essential in realizing competitive advantage. Through this concept, companies are required to engage in economy in forms of efficiency, effectiveness, and innovativeness to achieve best business practices and create added value.

Changes in technology also affect company performance. To avoid obsolescence and encourage innovation, companies must be aware of technological changes that might affect the industry. Creative technology adaptation can open opportunities for the creation of new products, improvements to existing products, or improvements in production and marketing techniques. Technological breakthroughs can open up markets and new sophisticated products or can also shorten the life of production facilities. Technology forecasting can help protect and enhance the ability of companies in a growing industry. This forecast makes strategic managers aware of the challenges and opportunities that promise. The key to useful technological advance forecasting lies in accurate estimation of the impact of future technological changes and their possible impacts. A comprehensive analysis of the effects of technological change includes a review of the expected impact of new technology on the distant environment, on the situation of business competition, and on the business interface of society. Manufacturers, banks and retailers have taken advantage of this technological advancement in their business in order to facilitate and speed up services to satisfy customer needs. The industrial environment also plays a role in accelerating environmental change. The industrial environment in question is, bargaining power of buyers. bargaining power of sellers, the entry of potential new entrants, the presence of substitute goods, and the intensity of company competition in the industry. From the company's point of view all the factors above are factors that are beyond the company's control as external factors. All external factors provide opportunities and threats for the company to realize the company's vision, mission and goals. The external factors above cannot be controlled by the company without the right strategy and in accordance with the changing environment situation. The strategy formulated by the company is a management expertise in managing the company. The strategy is actually a management activity to strengthen the organization's position. Without a strategy in managing the company, a manager seems to step into uncertainty. Management with all its expertise is required to develop strategies that are suitable for the company they lead. Strategic planning is a systematic management process that can be interpreted as a decision making process for programs to be carried out by the organization and an estimated amount of resources that will be allocated in each program during the next few years (Anthony \& Govindarajan, 2004). Strategic planning occupies a crucial position, because it determines the comprehensive, coherent, and balanced long-term plans and short-term plans produced by the organization (Kusmayadi, 2008).

Darya (2012) states that environmental factors play an important role for companies, especially in choosing the direction and formulation of corporate strategy. Changes in the environment both internal and external require the company's capabilities to be able to adapt to these changes so that the survival of the company remains. Meanwhile, planning is a tool to adapt and is also a determining factor for company performance so that it is expected to create competitive advantage. In general, a company's environment consists of groups that are interrelated with one another who play an important role in determining the opportunities, challenges and obstacles facing the company. The external environment of a company presents many challenges faced by a company in an effort to attract or obtain the necessary resources and to market goods and services profitably (Pearce and 
Robinson 1997; Hunger and Wheleen, 2003).

Utama (2009) stated that environmental adaptability reflects the ability to adapt to an uncertain environment that is the ability to adapt to changes in legislation, technological changes, changes in market tastes. According to Montoya-Weiss and Calantone (1994), McGinnis and Kohn (1993), changes in legislation, technological developments, consumption pattern are important aspects to find out how far the organization is able to adapt in a new environment. Lathifah (2007) found that the level of turbulences of the external environment of rapid technological development also requires companies to build on their adaptability and accessibility capabilities. The strength of adaptability in question is the ability of the entire potential of the company to immediately adjust to the needs and desires, both consumers, suppliers, and other parties who have the power of influence on the market. The technological orientation of the industry refers to the level at which the industry is considered in the technology intensive industry. The technological aspects applied to the product both in terms of production and applied technology owned by the product are measured through a unique level of technological orientation. This technology-based adaptation will measure how far a company or organization is able to use technology as a basis for competitive advantage, and in strategic policy making. On the side, there are several important components of external analysis covering several aspects as the focus of adaptability. First, scanning is an attempt to identify the initial clues from environmental changes and trends. Second, monitoring to detect meaning through continuous observation of environmental changes and trends. Third, forecasting refers to the development of projections for anticipated results based on monitored changes and trends. Fourth, assessment is determining the time and importance of changes and environmental trends for corporate and management strategies.

\section{Digital Entrepreneurship: Recent Developments and Critical Points}

Globalization and the great development of information and communication technology (ICT) has created a major transformation in the world economy. Advances in information communication technology and business innovation in ICT have created a new form of digital economy (Cohen et al., 2000; Pohjola 2002; Hafezieh et al., 2011). Davidson and Vaast (2010) revealed that entrepreneurship in the digital economy is characterized by three interrelated types of entrepreneurship that create opportunities for business entrepreneurship, knowledge entrepreneurship, and institutional entrepreneurship. Entrepreneurship Digital technology has had a tremendous impact on the world. Digital businesses built through internet networks from world-class digital-based companies through social media services, for example, have been able to change the world and have shaped communication patterns without geographical barriers. Digitization also impacts the development of new entrepreneurs (Hayati \& Caniago, 2019). The potential for new business development increases due to the opportunity to digitize business branches and change businesses from offline to online. The positive impact of digitalization on entrepreneurship also occurs in the form of promoting innovation, creating job opportunities, and increasing productivity.

The latest developments in entrepreneurship driven by technological development and the combination of ICT as the driving force have created specific characteristics and impacts on digital entrepreneurship. Giones and Brem (2017), identify interrelated characters of digital entrepreneurship with the impact of entrepreneurial digitalization on economic and socio-cultural patterns. Furthermore, Tony Bailetti (2012) defines technology entrepreneurship as an investment that utilizes advances in knowledge and technology to create organizational value. Ferreira et al. (2016) conceptualize technology entrepreneurship as a combination of entrepreneurship and technology-based innovation. Beckman et al., (2012) defines technological entrepreneurship as innovation to take advantage of opportunities from technological developments. Another advancement of digital entrepreneurship is digital technology entrepreneurship. This refers to the use of ICT technology and the use of the Internet of Things in the products or services offered (Giones \& Brem, 2017). Some examples are the widespread use of smartphones today to generate innovation in 
transactions, online sales, and traction, market validation, scalability and business growth. This form is different from digital entrepreneurship which refers to the use of the internet base in new products and services by the use of big data and artificial intelligence (Wallin et al., 2016; Tomczak \& Brem, 2013). The latest forms of entrepreneurship form a new economic cluster called the creative economy as a concept in a new economic era whose main support is information and creativity where ideas and stock of knowledge from human resources are the main production factors in economic activity.

In the corporate context, the capacity to utilize digital entrepreneurship is characterized by the intensity of using the internet as a medium of communication, collaboration, and cooperation to develop business or trade transactions for products and services. This shows that digital entrepreneurship specifically examines the impact of information technology on business and service development by utilizing the internet (Mustikawati \& Afiff, 2018). Don Tapscott (2010) found several characteristics of digital entrepreneurship in the form of digitization, virtualization, internetworking and convergence. Digitization refers to products and forms of service being changed into formats one and number, and virtualization changes physical things can become virtual. Internetworking refers to network economics with deep interconnection and range of economic entities, and convergence includes the convergence of computing, communication, and content. In the context of marketing, Beier (2016) states that the marketing process in the digital world must also be understood by digital start-up owners, digital marketing in general can be defined as the use of integrated digital technology (Nugraha \& Wahyuhastuti, 2017). Other definitions also describe targeted and measurable communication aimed at obtaining and retaining customers and at the same time by building deeper relationships with them (Wymbs, 2011). Digital entrepreneurship emphasizes the development of ideas and the creation of values and opportunities by the utilization of scientific and technological knowledge (Nugraha \& Wahyuhastuti, 2017). Richter et al. (2017) states that digital entrepreneurship is an effort to gain market share, business opportunities that make money and try to be innovative, radical and risk takers. Esmaeeli (2011) states that digital entrepreneurship develops business digitalization of digital services that is relatively fast and satisfying so that it is chosen to make almost all services digital, the potential of goods or services is wider with digital distribution channels, the potential for digital interaction with stakeholders, and digital potential from internal activities related to company operations. Digital business explains the creation of new value, which involves new business models based on digital goods or services, digital distribution, digital workplaces, and digital markets.

The development of digital entrepreneurship starts from the stage of a start-up which develops the initial idea to get the results of his hard work. There are three stages in the development of digital business, namely the stage of idea development, then the development of a starter business and then business management (Le Dinh et al., 2018). The essence of digital entrepreneurship is the founder of the business itself. It is important to get a stable business founding team to start a business with a typical trial-error in the early stages of building a business network and social capital (Spiegel et al., 2016). In addition, the development of digital entrepreneurship also requires the development of a digital platform as a digital space that provides business opportunities for interconnection between business people and customers (Hsieh and $\mathrm{Wu}, 2018$ ). The platform can be divided into three namely innovation platforms as offered by Google, transaction platforms, such as retail or online service requests, and integration platforms, which are a combination of innovation and transaction platforms (Hayati, \& Caniago, 2019).

\section{Conclusion}

The technological aspects applied to the product both in terms of production and applied technology owned by the product are measured through a unique level of technological orientation. In general, creative technology adaptation can open opportunities for the creation of new products, improvement of existing products, or improvements in production and marketing techniques. However, today technology-based adaptation is considered more able to measure how far the 
company or organization is able to use technology as the basis for competitive advantage, value creation and opportunities and in strategic policy making. For conventional companies, the adaptive response is shown by identifying the influence of the external environment such as scanning, monitoring, forecasting, and assessing. In this form of adaptation, the company's efforts to analyze and identify demands and shifts in the market are spent through continuous efforts on changes and environmental trends. This effort refers to developing projections for anticipated results based on changes and identified trends that will consume resources. This form of digital entrepreneurship considers technology not as an external factor that needs to be responded to as challenges and obstacles, rather than developing information technology to develop digital-based products and services. This encourages a paradigm shift in seeing the effect of technology on organizational survival. This shift encourages internet-based companies to be more able to dominate the market, and can create new consumption patterns altogether compared to focusing on efforts to make technology as an added value, as in conventional products and organizations.

\section{Reference}

Anthony, R. N. \& Govindarajan, V. (20040. Management Control System. McGraw Hill.

Bailetti, T. (2012). Technology entrepreneurship: overview, definition, and distinctive aspects. Technology Innovation Management Review, 2(2).

Beckman, C., Eisenhardt, K., Kotha, S., Meyer, A., \& Rajagopalan, N. (2012). Technology entrepreneurship. Strategic entrepreneurship journal, 6(2), 89-93.

Beier, M. (2016, September). Startups' Experimental Development of Digital Marketing Activities. A Case of Online-Videos. In A Case of Online-Videos (September 7, 2016). Paper has been presented at the 14th Interdisciplinary European Conference on Entrepreneurship Research (IECER), Chur, Switzerland.

Chung, W. W., Tan, K. H., Koh, S. L., Ojeda-Gomez, J., Simpson, M., \& Padmore, J. (2007). Achieving competitive advantage in the Mexican footwear industry. Benchmarking: An International Journal.

Clark, T., Varadarajan, P. R., \& Pride, W. M. (1994). Environmental management: The construct and research propositions. Journal of Business Research, 29(1), 23-38.

Cognoscenti Consulting Group. (2016). Importance of External and Industrial Environmental Studies for Company Strategies. Retrieved from http://ccg.co.id/blog/2016/o5/17/pentingnya-kajian-lingkungan-eksternal-danindustri-bagi-strategi-perusahaan/

Cohen, S. S., Zysman, J., \& DeLong, B. J. (200o). Tools for Thought: What is New and Important about the" Economy"?

Darya, I. G. P. (2012). The influence of environmental uncertainty and entrepreneurial characteristics on business competence and the performance of micro small businesses in the city of Balikpapan. Asian Journal of Innovation and Entrepreneurship, 1 (o1), 65-78.

Davidson, E., \& Vaast, E. (2010, January). Digital entrepreneurship and its sociomaterial enactment. In $201043 \mathrm{rd}$ Hawaii International Conference on System Sciences (pp. 1-10). IEEE.

Esmaeeli, H. (2011). The study of effecting factors on digital entrepreneurship (a case study). Interdisciplinary Journal of Contemporary Research in Business, 2(12), 163-172.

Esmaeeli, H. (2011). The study of effecting factors on digital entrepreneurship (a case study). Interdisciplinary Journal of Contemporary Research in Business, 2(12), $163-172$.

Ferreira, J. J., Ferreira, F. A., Fernandes, C. I., Jalali, M. S., Raposo, M. L., \& Marques, C. S. (2016). What do we [not] know about technology entrepreneurship research?. International Entrepreneurship and Management Journal, $12(3), 713-733$.

Giones, F., \& Brem, A. (2017). Digital technology entrepreneurship: A definition and research agenda. Technology Innovation Management Review, 7(5).

Guthrie, C. H. (2014). Who are we teaching? The learning expectations of" digital tribes" in the classroom. International Journal of e-Education, e-Business, e-Management and e-Learning, 4(2), 146.

Hafezieh, N., Akhavan, P., \& Eshraghian, F. (2011). Exploration of process and competitive factors of entrepreneurship in digital space. Education, Business and Society: Contemporary Middle Eastern Issues.

Hayati, K., \& Caniago, I. (2019). Digital technology entrepreneurship: the potential for empowering millennial businesses. Prosiding Sefila, 135-138.

Hsieh, Y. J., \& Wu, Y. J. (2019). Entrepreneurship through the platform strategy in the digital era: Insights and research opportunities. Computers in Human Behavior, 95, 315-323. 
Hunger, J. D., \& Wheelen, T. L. (2003). Essentials of strategic management. NJ: Prentice Hall.

Idris, I. (2018). The Influence of External Environment and Strategy Orientation on Company Performance (Case Study on Batik Tulis SMEs in Pantura, Central Java). Semarang: Universitas Diponegoro.

Kusmayadi, D. (2008). Influence of Business Environment on Company Performance: A Theoretical and Empirical Review. Jurnal Akuntansi FE Unsil, 3(2), 431.

Lathifah, D. N. (2007). Analysis of factors influencing the adaptation strategy of export promotion to improve export marketing performance (Case Study of Furniture Export Industry in Central Java) (Doctoral dissertation, Universitas Diponegoro).

Le Dinh, T., Vu, M. C., \& Ayayi, A. (2018). Towards a living lab for promoting the digital entrepreneurship process. International Journal of Entrepreneurship.

McGee, J. E., \& Rubach, M. J. (1996). The Role of Firm Size in Successful Outsourcing: A Study of New Computer Firms. Journal of Business and Entrepreneurship, 8(2), 9.

McGinnis, M. A., \& Kohn, J. W. (1993). Logistics strategy, organizational environment, and time competitiveness. Journal of Business Logistics, 14(2), 1.

Montoya-Weiss, M. M., \& Calantone, R. (1994). Determinants of new product performance: a review and metaanalysis. Journal of Product Innovation Management: An International Publication Of The Product Development \& Management Association, 11(5), 397-417.

Mustikawati, \& Afiff, F. (2018). Digital Entrepreneurs in the Creative Economy Era. STEBISIGM.

Nugraha, A. E. P., \& Wahyuhastuti, N. (2017). Digital business startup: as a solution to drive young entrepreneurs. Nusantara Journal of Business Management Application, 2(1), 1-9.

Pearce, J. A., \& Robinson, R. B. (1997). Strategic Management: Formulation. Implementation, and Control. Chicago: Irwin.

Pohjola, M. (2002). The new economy in growth and development. Oxford Review of Economic Policy, 18(3), 380396.

Richter, C., Kraus, S., Brem, A., Durst, S., \& Giselbrecht, C. (2017). Digital entrepreneurship: Innovative business models for the sharing economy. Creativity and Innovation Management, 26(3), 300-310.

Riyanto, S. (2018). Analysis of the influence of the internal and external environment on competitive advantage and the performance of small and medium businesses (SMEs) in Madison. Scientific Journal of Business Management and Innovation at Sam Ratulangi University., 5(3).

Setyowati, N. W. (2015). Influence of the External Environment and Internal Environment Against Competitive Advantage in Small and Medium Industries in Bandung, West Java. Essence: Journal of Business and Management, 5(1).

Spiegel, O., Abbassi, P., Zylka, M. P., Schlagwein, D., Fischbach, K., \& Schoder, D. (2016). Business model development, founders' social capital and the success of early stage internet start-ups: a mixed-method study. Information Systems Journal, 26(5), 421-449.

Suyono, E. (2013). The influence of the external business environment, strategy formulation, and internal control on company performance (survey on Bpr/Bkk owned by the Government and Private Sector in the Districts of Banyumas and Purbalingga). Sustainable Competitive Advantage (SCA), 1(1).

Tan, J., \& Litschert, T. W. (1994). Ownership types and strategic groups in emerging economies. The Journal of Management Studies, 41(2004), 1105-1129.

Tapscott, D. (2010). Macrowikinomics. Penguin Canada.

Tomczak, A., \& Brem, A. (2013). A conceptualized investment model of crowdfunding. Venture Capital, 15(4), 335359.

Turban, E., Sharda, R., Aronson, J. E., \& King, D. (2008). Business intelligence: A managerial approach (pp. 58-59). Indiana: Pearson Prentice Hall.

Utama, M. M. (2009). Effect of Environmental Adaptability and Entrepreneurship Orientation on Alliance Quality to Improve Competitive Advantage (Case Study of PT. Pos Indonesia in West Java Region) (Doctoral dissertation, Universitas Diponegoro).

Wallin, A., Still, K., \& Henttonen, K. (2016). Entrepreneurial growth ambitions: The case of Finnish technology startups. Technology innovation management review, 6(10), 5-16.

Wymbs, C. (2011). Digital marketing: The time for a new "academic major" has arrived. Journal of Marketing Education, 33(1), 93-106. 